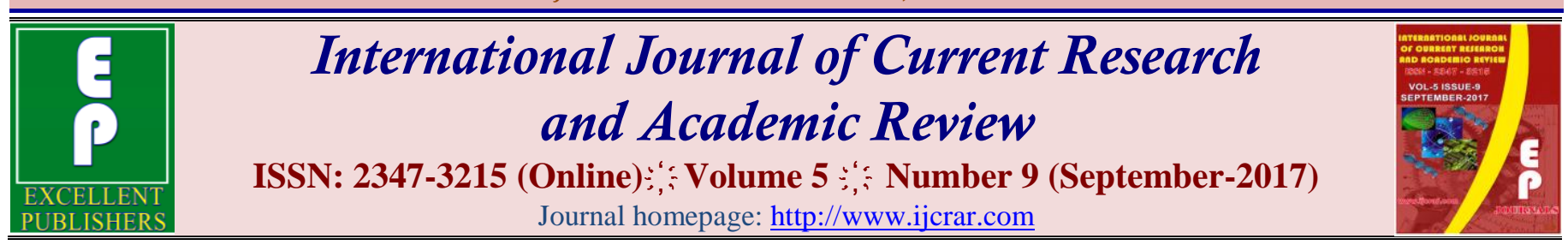

doi: https://doi.org/10.20546/ijcrar.2017.509.007

\title{
Palynological and Stomatal Characters Influenced by Gamma Rays in Gladiolus Cultivars
}

\author{
Neha Dogra ${ }^{1^{*}}$, K. K. Dhatt ${ }^{1}$ and Nirmaljit Kaur ${ }^{2}$ \\ ${ }^{1}$ Department of Floriculture and Landscaping, Punjab Agricultural University, Ludhiana (Punjab) - 141004, India \\ ${ }^{2}$ Department of Botany, Punjab Agricultural University, Ludhiana (Punjab) - 141004, India \\ *Corresponding author
}

\begin{tabular}{|c|c|}
\hline Abstract & Article Info \\
\hline \multirow{7}{*}{$\begin{array}{l}\text { An experiment was conducted at the experimental farm of Department of Floriculture } \\
\text { and Landscaping, Punjab Agricultural University Ludhiana (Punjab). Uniform size } \\
\text { ( } 4 \mathrm{~cm} \text { ) and healthy corms of gladiolus varieties viz. 'Punjab Glance' and 'Sylvia' were } \\
\text { irradiated with different doses }(0,50,100,125,150 \text { Gy) of gamma rays. Each treatment } \\
\text { was replicated thrice. Results revealed that pollen fertility, size, stomata number, size } \\
\text { and number of chloroplast decreased with the increasing dose of irradiation. In } \\
\text { acetocarmine test, pollen fertility was recorded maximum in non-irradiated pollen in } \\
\text { both varieties }(91.96,90.70 \%) \text { while minimum viability was observed in both varieties } \\
\text { treated with } 150 \mathrm{~Gy} \text {. Maximum pollen size, number of stomata, stomata size and } \\
\text { number of chloroplast per guard cell was recorded in } 50 \text { Gy and minimum at } 150 \mathrm{~Gy} \text { as } \\
\text { compared to control in both varieties. Out of two varieties 'Punjab Glance' exhibits }\end{array}$} & $\begin{array}{l}\text { Accepted: } 28 \text { August } 2017 \\
\text { Available Online: } 20 \text { September } 2017\end{array}$ \\
\hline & Keywords \\
\hline & \\
\hline & \\
\hline & Pollen Fertility, \\
\hline & $\begin{array}{l}\text { Stomata, } \\
\text { Chlorophyll }\end{array}$ \\
\hline & \\
\hline
\end{tabular}

\section{Introduction}

Gladiolus (Gladiolus hybridus L.) is an important bulbous flower crop and is very popular as cut flower both in domestic and international market. It belongs to family Iridaceae. It is universally acclaimed prestigious cut flower (Ram et al., 2005). It is relatively easy to grow and ideal for bedding and exhibition. In India, gladiolus is commercially grown in West Bengal, Maharashtra, Uttar Pradesh, Punjab, Delhi and Rajasthan (Singh, 2006). Ever increasing demand particularly in cities and towns of India make it an important cut flower which is now available in the Indian markets round the year. It is propagated through corms. Gamma rays are used for improving growth and quality of plants, for their high mutation frequency and can interact with atoms and molecules, thus producing free radicals in cells that affect morphology, anatomy, biochemistry and physiology of the plants (Chahal and Gosal, 2002). Mutation breeding by gamma rays is one of the most powerful methods for developing new varieties, which is very successful in ornamental crops. Jain (2006) stated that induced mutations are highly effective to enhance natural genetic resources for vegetatively propagated crops. Several improvements in ornamental crops could be achieved by gamma mutation, including characters of flowers, leaves, growth habit and physiological traits (Schum and Prell, 1998). Radiation mediated morphological, structural and functional changes in a plant are governed by the intensity and duration of the gamma rays which generally induce cytological, biochemical, physiological, morphological and 
genetically changes in cells and tissues (Chandrashekar et al., 2013).

The literary data on the pollen morphology of Iridaceae family is rather limited. Rodionenko (1961) researched the pollen grain morphology of 73 species of Iris, 24 species of Crocus, using light microscope. Pollen longevity largely depends on the abundance of sucrose which protects the membrane integrity (Hoekstra et al., 1989). Plant species with short-lived pollen contain low amounts of soluble carbohydrates, while those with longlived pollen have higher soluble carbohydrate content and include cytoplasmic polysaccharides. The effect of gamma radiation on pigment was studied by Palamine et al., (2005) and Jinxi (2006) on Anthurium andraeanum and dracaena and they found that 20 Gray decreased the ratio of chlorophylls $\mathrm{a}$ and $\mathrm{b}$ found a negative correlation between gamma dose and chlorophyll. Chandrashekar et al., (2013) on Terminalia arjuna, observed that chlorophyll content decreased with increasing doses. The aim of this study is to give a complete description of the surface structure of leaves and pollen grains of the gladiolus varieties 'Punjab Glance and Sylvia' through gamma irradiation.

\section{Materials and Methods}

The present investigation was carried out during 20142015 and 2015-2016 at experimental farm PAU Ludhiana, Punjab during winter season. The geographical location of PAU is at $30^{\circ}$ 54' North (latitude) and $75^{\circ} 48$ East (longitude) at the height of $247 \mathrm{~m}$ above the sea level. Uniform size $(4 \mathrm{~cm})$ and healthy corms of gladiolus varieties viz. 'Punjab Glance' and 'Sylvia' were irradiated with different doses $(0,50,100,125,150 \mathrm{~Gy})$ of gamma rays at College Orchard, Department of Fruit Science, Punjab Agricultural University, Ludhiana using gamma rays Low Dose Irradiator 2000 ANSI-N 433.1. These corms were planted in the field with in $24 \mathrm{hrs}$ of treatment with spacing of row to row $30 \mathrm{~cm}$ and corm to corm $20 \mathrm{~cm}$. The experiment was laid out in Randomized Block Design with three replications. Observations on palynological (pollen fertilty and size) and stomata characters (number of stomata, stomata size, number of chloroplast per guard cell and chlorophyll content) were recorded.

To determine the pollen fertility (\%), pollen grains collected soon after anthesis were stained with drop of acetocarmine and viewed under microscope (Leica Bright Field Research Microscope) at 200X. Uniformly stained and round pollens were considered as viable whereas unstained and broken as non-viable and the percent pollen fertility was worked out. Size of wellstained pollen grains (in $\mu \mathrm{m}$ ) was recorded under microscope for observing stomata characteristics.

A drop of an adhesive (Quick fix) was applied to the abaxial (lower) surface of leaf and spread thoroughly over an area of 1-2 $\mathrm{cm} 2$ during mid-day (11:00 -13:00 pm) while they are still attached to plant. When solidified, the replica containing impressions of epidermis and stomata was stripped off the leaf and observed under microscope.

To determine the number of chloroplasts per guard cell, a drop of I-KI was placed on the peel, removed from abaxial surface of leaf and allowed to react for $>5 \mathrm{~min}$. The peel was then washed with deionised water. Starch containing regions (chloroplasts) were stained. After washing, the peel was observed under microscope at $400 \mathrm{X}$.

To determine the chlorophyll content (Hiscox and Israelstam, 1979) freshly removed leaves were finely chopped and $50 \mathrm{mg}$ portion was dipped in a test tube containing $10 \mathrm{ml}$ of DMSO (Dimethyl Sulphoxide). The test tubes were then placed in an oven at $60{ }^{\circ} \mathrm{C}$ for about two hours to facilitate the extraction of pigments. After requisite period, the extract was allowed to reach the room temperature and absorbance was read at 645 and $665 \mathrm{~nm}$ on a spectrophotometer (SL- 171). The chlorophyll content was quantified by using the following equation:

Total Chlorophyll $=[20.2(\mathrm{~A} 645)+8.02(665)] \mathrm{x}$ $\mathrm{V} / 1000 \mathrm{xW}$

Total Soluble Sugar Content $(\mathrm{mg} / \mathrm{g}$ ) was determined based on the method given by (Dubois et al., 1951). Dried leaves $(0.1 \mathrm{~g})$ were added with $5 \mathrm{ml}$ of $80 \%$ ethanol to test tubes, placed in water bath, and heated for 1 hour at $80{ }^{\circ} \mathrm{C}$. Then, $1 \mathrm{ml}$ of the sample extract was taken in another set of test tubes and mixed with 1 $\mathrm{ml}$ each of $18 \%$ phenol and distilled water, and then allowed to stand at room temperature for an hour. Finally, $5 \mathrm{ml}$ of sulphuric acid was added and the whole mixture was vortexed. The absorbance was read at 490 $\mathrm{nm}$ wavelength on the UV spectrophotometer. Ethanol $80 \%$ was used as blank sample.During $1^{\text {st }}$ and $2^{\text {nd }}$ years pooled data for all the parameters were statistical analyzed using Duncan Multiple Range Test, (Duncan 1955). 


\section{Results and Discussion}

\section{Radiation effect on Palynological characters}

To study the effect of gamma rays on palynological characters, observations were recorded on parameters viz. pollen fertility and pollen size are presented in Table 1.

The appraisal of table elucidate that gamma ray treatment have significantly affected the pollen fertility in both varieties in Plate 1. At higher doses of gamma rays more pollen grains were remain unstained which shows reduction in fertility. Maximum pollen fertility $(91.33 \%)$ was recorded in untreated corms i.e. control which was at par with 50 Gy $(81.56 \%)$ and 100 Gy $(70.37 \%)$. The results also indicate that pollen fertility decreased significantly at 150 Gy gamma rays treatment $(42.50 \%)$. Out of two varieties, maximum pollen fertility was recorded in variety 'Punjab Glance' (70.61\%) and it was $67.13 \%$ in 'Sylvia'. The data of interaction reveals that among varieties and gamma rays treatments that maximum pollen fertility $(92.74 \%)$ in variety 'Punjab Glance' during the second year in control followed by $(91.19 \%)$ in first year at control. Pollen Fertility was decreased as the dose of gamma rays was increased to $150 \mathrm{~Gy}$. Minimum fertility of pollen was observed in 'Sylvia' (40.41\%) during first year.

The critical rummage of data indicates that different doses of gamma rays had significant effect on pollen size in gladiolus varieties 'Punjab Glance' and 'Sylvia'. Maximum pollen size $(34.34 \mu \mathrm{m})$ was recorded in treated corms at $50 \mathrm{~Gy}$ which were at par with control $(33.60 \mu \mathrm{m})$ and $100 \mathrm{~Gy}(26.82 \mu \mathrm{m})$. Pollen size was decreased significantly at $150 \mathrm{~Gy}(16.13 \mu \mathrm{m})$. Out of two varieties, maximum pollen size was recorded in variety 'Punjab Glance' $(28.64 \mu \mathrm{m})$. It was $26.42 \mu \mathrm{m}$ in 'Sylvia'. The data of interaction reveals that among varieties, gamma rays treatment and years indicate that maximum pollen size $(36.48 \mu \mathrm{m})$ was found in variety 'Punjab Glance' during the second year at 50 Gy followed $(36.00 \mu \mathrm{m})$ in second year at $0 \mathrm{~Gy}$. Pollen size decreased as the dose of gamma rays were increased to $150 \mathrm{~Gy}$. The minimum pollen size was observed in $(15.37 \mu \mathrm{m})$ in 'Sylvia' during first year.

\section{Radiation effect on Stomatal characters}

The appraisal of table elucidate that gamma rays treatment have significantly affected the number of stomata in both varieties are presented in Table 1.
Maximum stomata number $\left(15.11 \mathrm{~mm}^{2}\right)$ was recorded at $50 \mathrm{~Gy}$ which was at par with control $\left(14.59 \mathrm{~mm}^{2}\right)$ and $100 \mathrm{~Gy}\left(12.26 \mathrm{~mm}^{2}\right)$. Number of stomata was decreased significantly at 150 Gy gamma rays treatment (5.12 $\mathrm{mm}^{2}$ ).

Out of two varieties, maximum stomata number was recorded in variety 'Punjab Glance' $\left(11.58 \mathrm{~mm}^{2}\right)$. It was $10.60 \mathrm{~mm}^{2}$ in 'Sylvia'.

The data of interaction reveals that among varieties, gamma rays treatment and years indicate that maximum stomata size $\left(15.89 \mathrm{~mm}^{2}\right)$ in variety 'Punjab Glance' during the second year at 50 Gy followed by (15.61 $\mathrm{mm}^{2}$ ) in second year at $0 \mathrm{~Gy}$. Number of stomata was decreased as the dose of gamma rays were increased to 150 Gy that is minimum number of stomata was recorded in $\left(4.78 \mathrm{~mm}^{2}\right)$ in 'Sylvia' during first year.

The appraisal of table elucidates that gamma rays treatment have significantly affected the stomata size in both varieties are presented in Fig 1. Maximum stomata size $(31.70 \mu \mathrm{m})$ was recorded in treated corms which were at par with control $(25.90 \mu \mathrm{m})$ and 100 Gy $(21.09$ $\mu \mathrm{m})$.

Stomata size was decreased significantly at 150 Gy gamma rays treatment $(8.88 \mu \mathrm{m})$. Out of two varieties, maximum stomata size was recorded in variety 'Punjab Glance' $(21.57 \mu \mathrm{m})$. It was $20.20 \mu \mathrm{m}$ in 'Sylvia'.

A significant difference was recorded in number of chloroplast per guard cell, after gamma ray treatment in both varieties. Maximum number of chloroplast per guard cell (6.66) was recorded at 50 Gy which was at par with control (5.46) and $100 \mathrm{~Gy}$ (4.79). It is evident from the results that chloroplast number per guard cell decreased significantly at 150 Gy gamma rays treatment (2.72). Out of two varieties, maximum number of chloroplast was recorded in variety 'Punjab Glance' (4.86). It was 4.44 in 'Sylvia'.

The observation recorded on chlorophyll content of gladiolus varieties 'Punjab Glance' and 'Sylvia' treated with different doses of gamma rays are presented in Fig. 2 Maximum chlorophyll content $\left(0.067 \mathrm{mg} \mathrm{g}^{-1}\right)$ was recorded at 50 Gy which was at par with $0 \mathrm{~Gy}(0.063 \mathrm{mg}$ $\left.\mathrm{g}^{-1}\right)$ and $100 \mathrm{~Gy}\left(0.058 \mathrm{mg} \mathrm{g}^{-1}\right)$. Chlorophyll content was decreased significantly at $150 \mathrm{~Gy}$ gamma rays treatment $\left(0.034 \mathrm{mg} \mathrm{g}^{-1}\right)$. Out of two varieties, maximum chlorophyll content was recorded in variety 'Punjab Glance' $\left(0.598 \mathrm{mg} \mathrm{g}^{-1}\right)$. It was $0.474 \mathrm{mg} \mathrm{g}^{-1}$ in 'Sylvia'. 
Int.J.Curr.Res.Aca.Rev.2017; 5(9): 44-50

Table.1 Effect of different doses of gamma rays on palynological and stomatal studies of gladiolus varieties 'Punjab Glance' and 'Sylvia'

\begin{tabular}{|c|c|c|c|c|c|c|c|c|c|c|c|c|c|c|c|}
\hline \multirow{3}{*}{$\begin{array}{c}\text { Doses of } \\
\text { gamma } \\
\text { rays (Gy) } \\
\text { Treatments }\end{array}$} & \multicolumn{5}{|c|}{ Pollen fertility $(\%)$} & \multicolumn{5}{|c|}{ Pollen Size $(\mu \mathrm{m})$} & \multicolumn{5}{|c|}{ Number of Stomata $\left(\mathrm{mm}^{2}\right)$} \\
\hline & \multicolumn{2}{|c|}{ Punjab Glance } & \multicolumn{2}{|c|}{ Sylvia } & \multirow[t]{2}{*}{ Mean } & \multicolumn{2}{|c|}{ Punjab Glance } & \multicolumn{2}{|c|}{ Sylvia } & \multirow[t]{2}{*}{ Mean } & \multicolumn{2}{|c|}{ Punjab Glance } & \multicolumn{2}{|c|}{ Sylvia } & \multirow[t]{2}{*}{ Mean } \\
\hline & $\begin{array}{c}2014- \\
15\end{array}$ & $\begin{array}{c}2015- \\
16\end{array}$ & $\begin{array}{c}2014- \\
15\end{array}$ & $\begin{array}{c}2015- \\
16\end{array}$ & & $\begin{array}{c}2014- \\
15\end{array}$ & $\begin{array}{c}2015- \\
16\end{array}$ & $\begin{array}{c}2014- \\
15\end{array}$ & $\begin{array}{c}2015- \\
16\end{array}$ & & $\begin{array}{c}2014- \\
15\end{array}$ & $\begin{array}{c}2015- \\
16\end{array}$ & $\begin{array}{c}2014- \\
15\end{array}$ & $\begin{array}{c}2015- \\
16\end{array}$ & \\
\hline 0 (control) & 91.19 & 92.74 & 90.34 & 91.07 & $91.33^{\mathrm{a}}$ & 34.41 & 36.00 & 31.15 & 32.85 & $33.60^{\mathrm{a}}$ & 14.98 & 15.61 & 13.78 & 14.00 & $14.59^{\mathrm{a}}$ \\
\hline 50 & 82.74 & 85.15 & 78.45 & 79.93 & $81.56^{\mathrm{b}}$ & 35.25 & 36.48 & 32.19 & 33.45 & $34.34^{\mathrm{a}}$ & 15.26 & 15.89 & 14.52 & 14.81 & $15.11^{\mathrm{a}}$ \\
\hline 100 & 70.00 & 72.48 & 69.08 & 69.93 & $70.37^{\mathrm{c}}$ & 27.11 & 27.48 & 25.52 & 27.19 & $26.82^{\mathrm{b}}$ & 12.37 & 12.82 & 11.82 & 12.07 & $12.26^{\mathrm{b}}$ \\
\hline 125 & 54.52 & 57.37 & 51.59 & 53.00 & $54.11^{\mathrm{d}}$ & 24.63 & 26.37 & 21.00 & 22.34 & $23.58^{\mathrm{c}}$ & 7.93 & 8.19 & 6.97 & 7.11 & $7.55^{\mathrm{c}}$ \\
\hline 150 & 42.52 & 45.34 & 40.41 & 41.74 & $42.50^{\mathrm{e}}$ & 15.97 & 16.89 & 15.37 & 16.30 & $16.13^{\mathrm{d}}$ & 5.26 & 5.41 & 4.78 & 5.04 & $5.12^{\mathrm{d}}$ \\
\hline Mean & 68.19 & 70.61 & 65.97 & 67.13 & 67.97 & 27.47 & 28.64 & 25.04 & 26.42 & 26.89 & 11.16 & 11.58 & 10.37 & 10.60 & 10.92 \\
\hline $\operatorname{LSD}^{(\mathrm{p}=0.05)}$ & \multicolumn{5}{|c|}{$\begin{array}{l}\text { Treatments }(\mathrm{A})=1.84 ; \text { Varieties }(\mathrm{B})=1.16 ; \mathrm{A} \times \mathrm{B} \\
=1.64\end{array}$} & \multicolumn{5}{|c|}{$\begin{array}{l}\text { Treatments }(A)=1.88 ; \text { Varieties }(B)=1.19 ; \mathrm{A} x \\
\mathrm{~B}=1.68\end{array}$} & \multicolumn{5}{|c|}{$\begin{array}{l}\text { Treatments }(A)=0.68 ; \text { Varieties }(B)=0.43 ; A x \\
B=0.61\end{array}$} \\
\hline
\end{tabular}

Fig.1 Effect of gamma irradiation on Stomata Size and Number of chloroplasts in gladiolus varieties 'Punjab Glance 'and 'Sylvia'
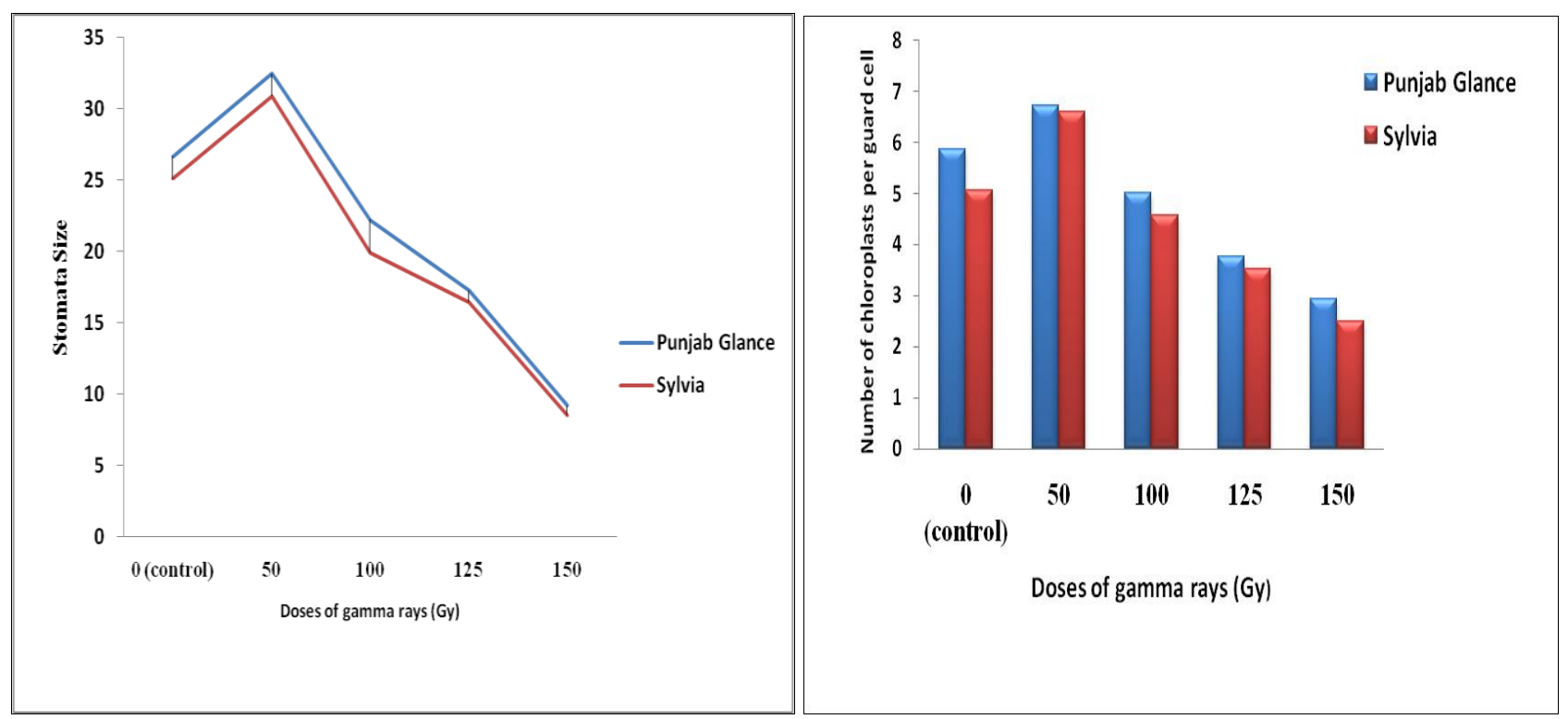
Fig.2 Effect of gamma irradiation on chlorophyll content $\left(\mathrm{mg} \mathrm{g}^{-1}\right)$ and Total Soluble Sugars of gladiolus varieties 'Punjab Glance 'and 'Sylvia'
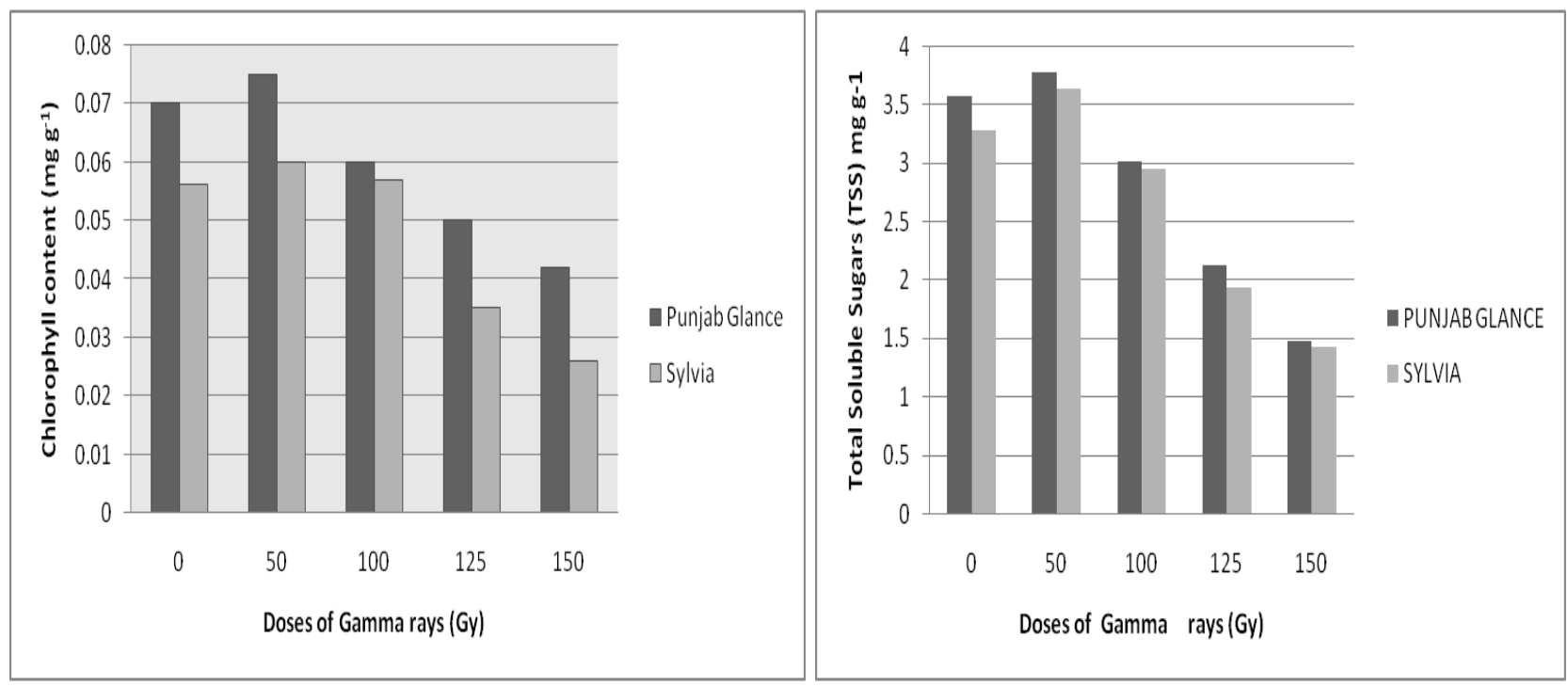

Plate.1 Pollen grains under Leica Bright Field Research Microscope

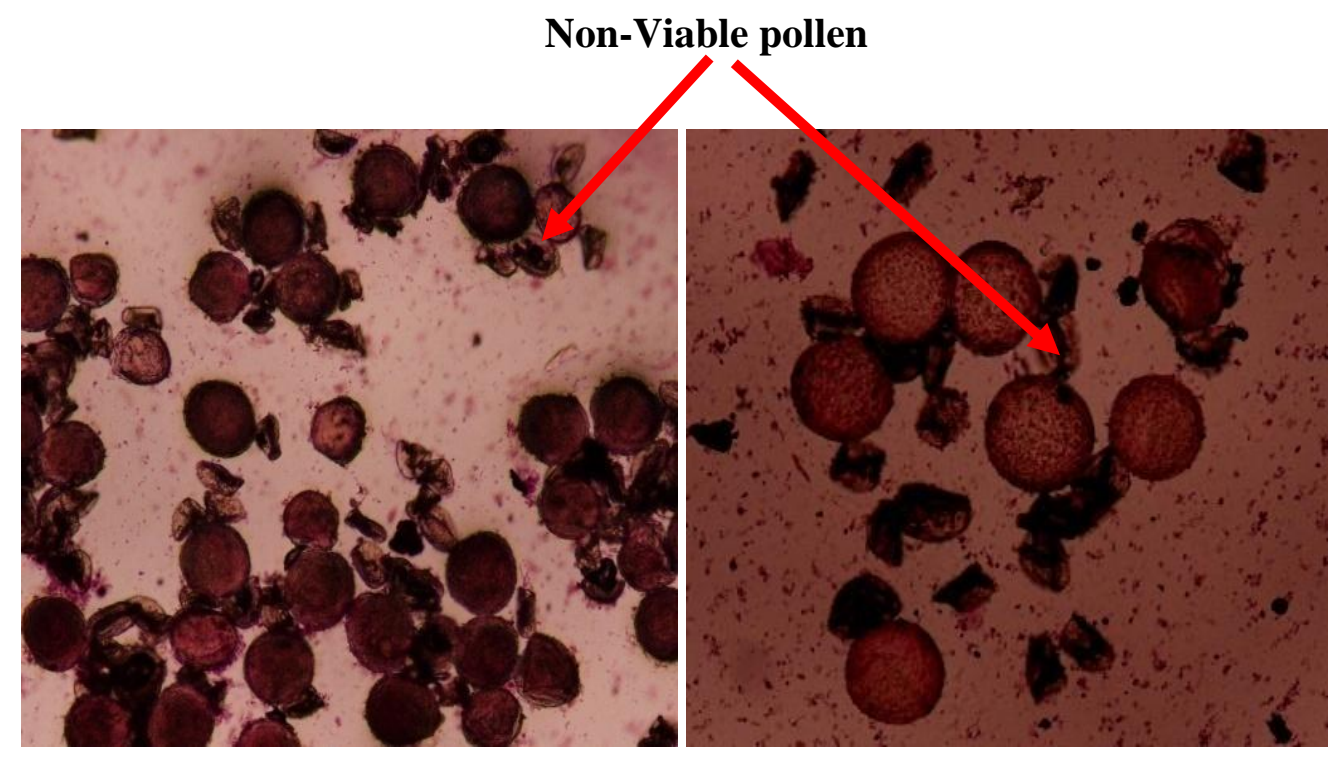

Punjab Glance (100 Gy)

Svlvia $(100$ 
It is evident from the Fig 2 indicates that treatment of corms with gamma rays have significant effect on sugars in varieties 'Punjab Glance' and 'Sylvia'. Maximum soluble sugars $\left(2.40 \mathrm{mg} \mathrm{g}^{-1}\right)$ were recorded at $50 \mathrm{~Gy}$ which was at par with $0 \mathrm{gy}\left(2.10 \mathrm{mg} \mathrm{g}^{-1}\right)$ and $100 \mathrm{~Gy}$ $\left(1.90 \mathrm{mg} \mathrm{g}^{-1}\right)$. Sugar content was decreased significantly at $150 \mathrm{~Gy}$ gamma rays treatment $\left(1.06 \mathrm{mg} \mathrm{g}^{-1}\right)$. Out of two varieties maximum sugar content was recorded in variety 'Punjab Glance' (1.91 $\left.\mathrm{mg} \mathrm{g}^{-1}\right)$. It was $1.64 \mathrm{mg} \mathrm{g}^{-1}$ in 'Sylvia'.

The decrease in pollen viability is mostly caused by excessive nutrient consumption due to high intensity of irradiation. Low dose of gamma rays contains starch and has high amount of sugars which provides the respiratory substrates for pollen and extends pollen viability. The reduction in pollen fertility is due to chromosomal aberrations and the rate of reduction in pollen fertility increased at higher doses. This might be due to high amount of chromosomal damage by gamma irradiation (Kumar et al., 2013). Irregular meiosis is known to result in high pollen sterility following gamma rays treatment in gladiolus (Buiatti and Ragazzini 1965). Datta (1988) also obtained similar palynological investigation of mutants developed after gamma irradiation and colchicines treatment in chrysanthemum. Dhaduk (1992) had similar results in which he found reduction in pollen fertility in cvs. 'Melody', 'Rose Supreme' with $7 \mathrm{kR}$ and $10 \mathrm{kR}$ of gladiolus. Matsuo and Onozawa (1961) reported that gamma radiation generally reduces the reproductive ability of the plant and increases the number of sterile pollen much more than the environmental effects.

Siginificant decrease in number of stomata has been recorded in both varieties after gamma irradiation. Banerji et al., (1996) irradiated rooted cutting of chrysanthemum cv. 'Navneet' with 1.5, 2.0, 2.5, 4.0, 6.0 and $8.0 \mathrm{kRad}$ of gamma rays and observed reduction in stomata number. Significant difference was recorded by Datta and Banerji (1993) for number of chloroplasts per guard cell in mutants developed after gamma rays treatment.

Irradiation caused some breakdown in chloroplastic structure resulting more degradation of chlorophyll. Hasbullah et al., (2012) reported that chlorophyll was insensitive at low doses. The chlorophyll content of plants decreased after irradiation which might be due to the release of chlorophyll from its protein complex (Saha et al., 2010).

\section{References}

Banerji B K, A K Dwivedi and S K Datta. 1996. Gamma irradiation studies on rose and chrysanthemum. $J$ Nucl Agric Biol 25: 63-67

Buiatti M and R Ragazzini.1965. Gamma ray induced changes in the carnation (Dianthus caryophyllus L.). Radiat Bot 5:99-105.

Chahal G S and S S Gosal. 2002. Principles and procedures of plant breeding. Alpha Sci. International: 399-12

Chandrashekar K R, H M Somashekarappa and J Souframanien. 2013. Effect of gamma irradiation on germination, growth and biochemical parameters of Terminalia arjuna. Radi Prot Eniv 36:38-44.

Datta S K and B K Banerji. 1993. Gamma ray induced somatic mutation in chrysanthemum cv. 'Kalyani Mauve'. J Nuclear Agric Biol 22: 58-61.

Datta S K. 1988. 'Agnishikha'- A new chrysanthemum cultivar evoved by gamma irradiation. Floriculture. 9:10

Dhaduk B K. 1992. Induction of mutations in garden gladiolus by gamma rays. Ph.D Thesis, IARI New Delhi.

Dubois, M. K. J K Gilles, P A Hammiltron, Robers and F. Smith. 1951. Estimation of soluble sugar contents through phenol-silphuric acid method. Ann. Chemistry 26: 351-356.

Duncan, D. B. 1955. Multiple range and multiple F tests. Biometrics 11:1-42.

Hiscox J D and G F Israelstam. 1979. A method for the extraction of chlorophyll from leaf tissue without maceration. Canadian J Bot. 57: 1332-1334.

Hoekstra, F. A, L M. Crowe and J H Crowe. 1989. Differential desiccation sensitivity of corn and Pennisetum pollen linked to their sucrose content. Plt Cell Env. 12: 83-91.

Hoekstra, F. A. and T Van Roekel. 1988. Desiccation tolerance of Papaver dubium L. pollen during its development in the anther. Plt Physio 88: 626-632.

Jain S M. 2006. Major mutation assisted plant breeding programs supported by the FAO and IAEA. Plant Cell Tiss and Org Cult 82: 113-23.

Jinxi, F. 2006. Effect of radiation of gamma 60Co ray on dissoluble sugar and starch content of Anthurium andraeanum. Journal of Anhui Agricultural Sciences, 34: 616.

Kumar D P, A Chaturvedi, M Sreedhar, M Aparna, P Venubabu and R K Singhal. 2013 Impact of gamma irradiation stress on plant height and pollen fertility in Rice. Asian J Exp Biol Sci 4: 129-33. 
Matsuo, T and Y Onozawa. 1961. Mutations induced in rice by ionizing radiations and chemicals. In: Effects of Ionizing Radiations on Seeds, IAEA,Vienna. 5: 495-501.

Palamine, M. T., R. G. Cureg, L. J. Marbella, A. G. Lapade, Z. B. Domingo and C. C.Deocaris, 2005. Some biophysical changes in the chloroplasts of a dracaena radiation-mutant. Phili J Sci 134: 121126.

Ram R B, K S Tomar and S K Datta. 2005. Performance of certain gladiolus cultivars under sodic conditions. J Orn Hort 8: 77-78.

How to cite this article:

Neha Dogra, K. K. Dhatt and Nirmaljit Kaur. 2017. Palynological and Stomatal Characters Influenced by Gamma Rays in Gladiolus Cultivars. Int.J.Curr.Res.Aca.Rev. 5(9), 44-50.

doi: https://doi.org/10.20546/ijcrar.2017.509.007
Rodionenko G.I. 1961. Genus Iris - Iris L. Questions of morphology, biology, evolution and systematics. Publ. house of Acad. of Sci. of USSR, MoscowLeningrad: 23

Saha P, S S Raychaudhary, A Chakraborty and M Sudarshan. 2010 PIXE analysis of trace elements in relation to chlorophyll concentration in Plantago ovata Forsk. Appl Radiat Isol 68:44-49.

Schum A and W Preil. 1998. Induced mutations in ornamental plants. Springer Netherlands: 333-66.

Singh, A.K. 2006. Flower crops: Cultivation and management. Pub. New India, Publishing Agency, Pitam Pusa, New Delhi: p.147. 